\title{
Kombinasi Steganografi Berbasis Bit Matching dan Kriptografi DES untuk Pengamanan Data
}

\author{
Budi Prasetiyo $^{1}$, Rahmat Gernowo ${ }^{2}$ \& Beta Noranita ${ }^{3}$ \\ ${ }^{1}$ Jurusan Ilmu Komputer, Fakltas MIPA, Universitas Negeri Semarang \\ ${ }^{2,3}$ Program Magister Sistem Informasi, Universitas Diponegoro \\ Email: prasemath@gmail.com,rahmatgernowo@undip. ac. id \& bethznice@yahoo.com
}

\begin{abstract}
Abstrak. Pada penelitian ini dilakukan kombinasi steganografi dan kriptografi untuk pengamanan data dengan tidak mengubah kualitas media cover. Metode steganografi yang digunakan dengan melakukan pencocokan bit pesan pada bit MSB citra. Proses pencocokan dilakukan secara divide and conquer. Hasil indeks posisi bit kemudian dienkripsi menggunakan algoritma kriptografi Data Encryption Standard (DES). Masukkan data berupa pesan teks, citra, dan kunci. Output yang dihasilkan berupa chiperteks posisi bit yang dapat digunakan untuk merahasiakan data. Untuk mengetahui isi pesan semula diperlukan kunci dan citra yang sama.

Kombinasi yang dihasilkan dapat digunakan untuk pengamanan data. Kelebihan metode tersebut citra tidak mengalami perubahan kualitas dan kapasitas pesan yang disimpan dapat lebih besar dari citra. Hasil pengujian menunjukkan citra hitam putih maupun color dapat digunakan sebagai cover, kecuali citra $100 \%$ hitam dan $100 \%$ putih. Proses pencocokan pada warna citra yang bervariasi lebih cepat. Kerusakan pesan dengan penambahan noise salt and peper mulai terjadi pada nilai MSE 0,0067 dan gaussian mulai terjadi pada nilai MSE 0,00234 .
\end{abstract}

Kata kunci: Steganography; cryptography; bit matching; divide and conquer; DES.

\section{PENDAHULUAN}

Seiring perkembangan zaman, kebutuhan manusia akan informasi semakin meningkat. Ditengah-tengah perkembangan teknologi informasi yang kian semarak, internet tidak lagi menjamin penyediaan informasi yang aman. Berbagai mesin-pencari (search-engine) terus berkembang ditambah dengan serangan virus, penyadap, spam maupun hacker yang menjamur dapat mencuri data-data bersifat rahasia [1]. Mengatasi hal tersebut berbagai cara untuk meningkatkan keamanan data terus dikembangkan, diantaranya kriptografi dan steganografi. 
Budi Prasetiyo, dkk.

Steganografi adalah seni dan ilmu menyembunyikan data pada media lain sebagai cover (misalnya citra) sehingga terlihat samar [2]. Kriptografi adalah seni dan ilmu menjaga kerahasiaan data [3]. Pada kriptografi, data asli diubah menjadi bentuk lain yang tidak dapat dibaca. Penggabungan steganografi dan kriptografi secara bersamaan dapat meningkatkan pengamanan data [4].

Metode penggabungan steganografi dan kriptografi banyak dikembangkan. Pada umumnya teknik yang digunakan yaitu dengan mengenkripsi pesan terlebih dahulu (kriptografi), kemudian menyisipkannya ke media cover (steganografi) [5]. Namun, proses penyisipan dapat berpengaruh pada kualitas media cover tersebut. Upaya untuk meminimalisir perubahan kualitas cover dapat dilakukan dengan penyisipan pada bit terakhir (least significant bit). Perubahan kualitas cover tidak tampak kasat mata [6], tetapi penyisipan pada bit terakhir mengakibatkan cover rentan terhadap robust. Ketahanan terhadap robust dapat dilakukan dengan pemilihan pada bit pertama (most significant bit), tetapi justru perubahan kualitas cover menjadi besar dan dapat dicurigai.

Mengembangkan cara baru penggabungan steganografi dan kriptografi tanpa mengubah media cover. Teknik yang dilakukan yaitu dengan mencocokan bit pesan pada cover, kemudian dilanjutkan proses enkripsi (kriptografi). Salah satu algoritma kriptografi yang terkenal sejak 1977 dan menjadi standar adalah Data Encryption Standard (DES) [7].

Pada penelitian ini akan dilakukan kombinasi steganografi dan kriptografi tanpa mengubah media cover. Metode steganografi yang digunakan berbasis pencocokan bit (bit matching) pada bit pertama (most significant bit) dan metode kriptografi yang digunakan yaitu algoritma DES.

\section{METODOLOGI}

Metode yang digunakan yaitu penggabungan steganografi dengan kriptografi. Algoritma kriptografi yang digunakan adalah DES. Terdapat 2 proses didalam steganografi, yaitu embedding dan ekstraksi. Pada penelitian ini dibangun suatu perangkat lunak stego-kripto dengan model waterfall. Metode waterfall ditunjukkan pada Gambar 1. 


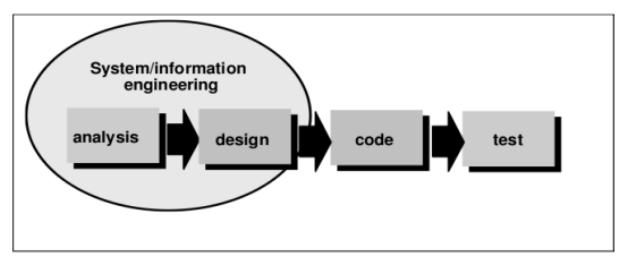

Gambar 1 Metode waterfall [8].

Metode waterfall membagi menjadi 4 tahap yang saling terkait dan mempengaruhi. Empat tahap tersebut yaitu analisa kebutuhan (analysis), desain (design), pengkodean (code) dan pengujian (test) [8]. Kombinasi kriptografi dan steganografi ini dibutuhkan 4 proses, yaitu pencocokan bit, enkripsi, dekripsi dan rekonstruksi yang secara rinci diuraikan sebagai berikut:

\subsection{Pencocokan Bit}

Pada penelitian ini metode pencocokan dilakukan secara divide and conquer [9]. Masukan pada proses ini adalah pesan dan citra.

Langkah-langkah yang dilakukan pada pencocokan bit adalah:

a) Mengkonversi pesan dan citra dalam bentuk biner

b) Mengambil nilai MSB citra

c) Melakukan pencocokan pesan pada MSB citra. Jika bit pesan terdapat pada MSB citra, maka dilanjutkan dengan menyimpan posisi indeks bit. Penyimpanan indeks terdiri dari posisi indeks bit awal (start) dan posisi indeks bit akhir (end). Jika proses pencocokan tidak terjadi, dilanjutkan proses d)

d) Membagi pesan menjadi dua bagian sama panjang kiri (L[i]) dan kanan (R[i])

e) Mengulangi langkah yang sama seperti pada nomor b), dengan L[i] dan R[i] sebagai masukan. Jika semua bit pesan terdapat pada citra, maka pencocokan selesai dan dilanjutkan proses f). Jika tidak, mengulangi langkah c) dengan L[i] dan R[i] sebagai masukkan hingga proses ke-i.

f) Menyimpan semua indeks bit hasil pencocokan

g) Keluaran berupa vektor yang memuat susunan indeks posisi bit.

Sebagai contoh, misalkan diketahui bit pesan dan bit citra sebagai berikut:

Pesan (P) : 10110111

Citra(C) : 100100011010110101010011

Karena $\mathrm{P}$ tidak terdapat pada $\mathrm{C}$ maka $\mathrm{P}$ dipecah menjadi dua bagian kiri (L) dan kanan (R), yaitu: 
1.L[1]: 1011 yang terletak pada posisi indeks "11, 14", yaitu: 100100011010110101010011.

2.R[1]: 0111, tidak terdapat pada citra, maka membagi $\mathrm{R}[1]$ menjadi dua bagian yaitu:

a. L[2]: 01 , terletak pada posisi indeks ke" 3 4"

b.R[2]: 11 , terletak pada posisi indeks ke" 9 "

3. Karena semua posisi bit sudah ditemukan, maka proses pencocokan selesai dan dilanjutkan langkah 4.

4. Menggabungkan semua solusi langkah 1, langkah 2a dan 2b. Diperoleh posisi indeks bit keseluruhan "11 143489 ".

\subsection{Enkripsi}

Vektor posisi bit yang diperoleh pada sub Bab 3. 1 kemudian di enkripsi. Proses enkripsi dilakukan dengan algoritma DES.

\subsection{Dekripsi}

Masukan pada proses ini adalah chiperteks dan kunci. Dekripsi terhadap cipherteks merupakan kebalikan dari proses enkripsi. DES menggunakan algoritma yang sama untuk proses enkripsi dan dekripsi. Pada proses dekripsi urutan kunci yang digunakan adalah kebalikanya yaitu $K_{16}, K_{15}, \ldots, K_{1}$. Untuk tiap putaran $16,15, \ldots, 1$, keluaran pada setiap putaran deciphering adalah:

$$
\begin{aligned}
& L_{i}=R_{i-1} \\
& R_{i}=L_{i-1} \oplus f\left(R_{i-1}, K_{i}\right)
\end{aligned}
$$

\subsection{Rekonstruksi}

Rekonstruksi bertujuan untuk mengembalikan pesan menjadi bentuk semula. Masukan pada tahap ini terdiri dari vektor indeks lokasi bit dan citra. Proses yang dilakukan yaitu dengan mengambil susunan bit citra berdasar vektor indeks lokasi bit. Hasil keluaran proses tersebut berupa susunan bit pesan.

Langkah-langkah yang dilakukan pada proses rekonstruksi adalah:

a) Mengkonversi citra dalam bentuk biner dan mengambil bit MSB citra.

b) Membaca setiap dua indeks isi vektor. Indeks pertama merupakan posisi awal bit (start) dan indeks kedua merupakan posisi akhir bit (end),

c) Mengambil nilai bit citra berdasarkan langkah b),

d) Mengulangi proses b) dan c) sampai posisi indeks terakhir.

e) Susunan bit yang terbentuk akan menghasilkan keluaran berupa susunan bit pesan. 
Sebagai contoh, misalkan diketahui vektor dan citra sebagai berikut:

Vektor : 11143489

Citra : 100100011010110101010011

Langkah ekstraksi yaitu dengan mengambil nilai bit citra berdasarkan lokasi vektor. Menyusun semua nilai bit hasil pencocokan dari vektor. Pada kasus tersebut diperoleh kecocokan yaitu:

a. Vektor 11 14, menghasilkan 1011

b. Vektor 34 , menghasilkan 01

c. Vektor 8 9, menghasilkan 11

Semua hasil diatas digabung, sehingga menghasilkan output 10110111.

\subsection{Kombinasi Steganografi dan Kriptografi}

\subsubsection{Gambaran Umum}

Kombinasi steganografi dan kriptografi pada penelitian ini terdiri dari 2 proses utama, yaitu proses embedding dan ekstraksi yang secara umum ditunjukkan pada Gambar 2.

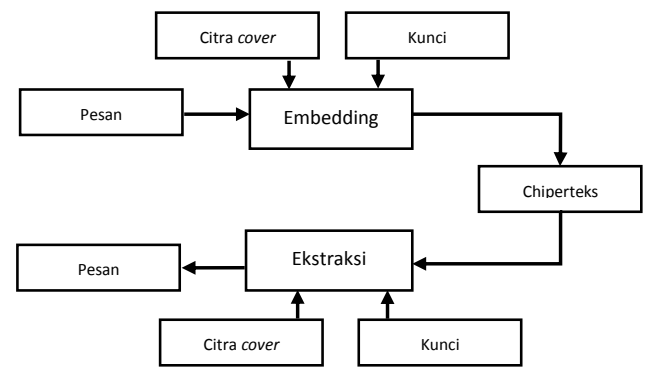

Gambar 2 Gambaran umum kombinasi steganografi dan kriptografi pada penelitian ini.

Proses embedding pada Gambar 3 terdiri dari pencocokan bit dan enkripsi, hasilnya chiperteks. Proses ekstraksi pada Gambar 5 terdiri dari dekripsi dan rekonstruksi, hasilnya berupa pesan.

\subsubsection{Proses Embedding}

Prosesembedding pada Gambar 3 bertujuan untuk menghasilkan indeks posisi bit. Masukkan proses embedding berupa pesan, citra dan kunci. 
Budi Prasetiyo, dkk.

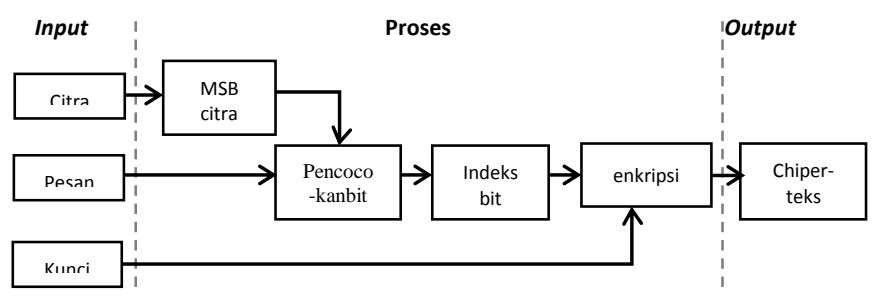

Gambar 3 Proses embedding.

Langkah-langkah embedding adalah sebagai berikut:

a. Memasukkan input berupa citra, pesan dan kunci.

b. Mengkonversi pesan dan citra dalam bentuk biner.

c. Mencocokan bit pesan dengan bit MSB citra. Posisi bit yang sama disimpan dalam vektor indeks bit.

d.Mengenkripsi vektor indeks bit dengan algoritma DES.

e. Hasil keluaran berupa chiperteks. Chiperteks tersebut memuat vektor indeks bit yang telah terenkripsi.

f. Selesai.

\subsubsection{Proses Ekstraksi}

Proses ekstraksi pada Gambar 4 bertujuan untuk mengembalikan pesan ke bentuk semula sehingga dapat diketahui isinya. Masukkan proses ekstraksi berupa chiperteks vektor, kunci dan citra.

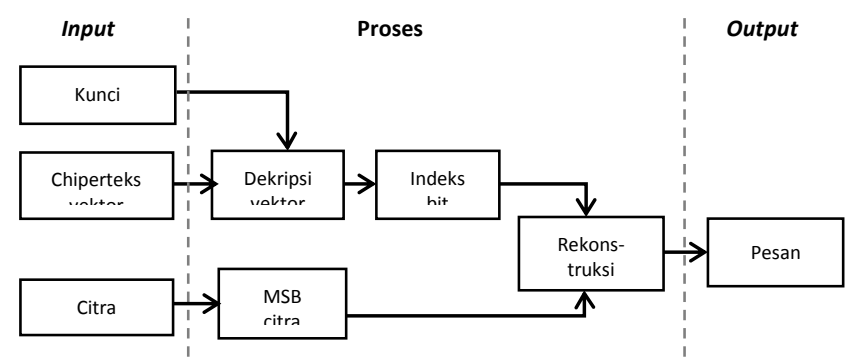

Gambar 4 Proses ekstraksi.

Langkah-langkah proses ekstraksi adalah sebagai berikut:

a. Memasukkan input berupa kunci, chiperteks vektor dan citra.

b. Mendekripsi vektor dengan kunci, hasil dekripsi berupa plainteks indeks bit.

c. Melakukan rekonstruksi pesan dengan mencocokan bit MSB citra berdasar vektor indeks bit.

d.Hasil output berupa pesan.

e. Selesai. 


\section{HASIL DAN PEMBAHASAN}

Hasil penelitian diimplementasikan kedalam bentuk program aplikasi yang dibangun menggunakan bahasa pemrograman matlab R2009a kemudian dilakukan pengujian untuk pengamanan data.

\subsection{Pengujian Citra}

\section{1) Proses Embedding}

Langkah-langkah untuk melakukan proses embedding adalah sebagai berikut:

a. Memilih file pesan yang akan di-embed. Pada kasus ini dipilih sebuah file transfer. txt dengan isi:

Transfer uang 50 juta via ATM.

Nomor rekening: 0123456

Password PIN: $9 x 8 d 7 g$

a. n. Budi Prasetiyo

b. Memilih citra sebagai cover file, misalnya Baboon.bmp yang terlihat pada Gambar 5.

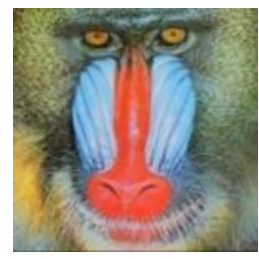

Gambar 5 Citra cover.

c. Mengetik password sebagai kunci untuk enkripsi DES, misalkan kunci: 1234567.

d. Setelah prosesEmbedding dihasilkan keluaran berupa indeks bit terlihat pada Gambar 6a dan chiperteks indeks bit terlihat pada Gambar 6b. 


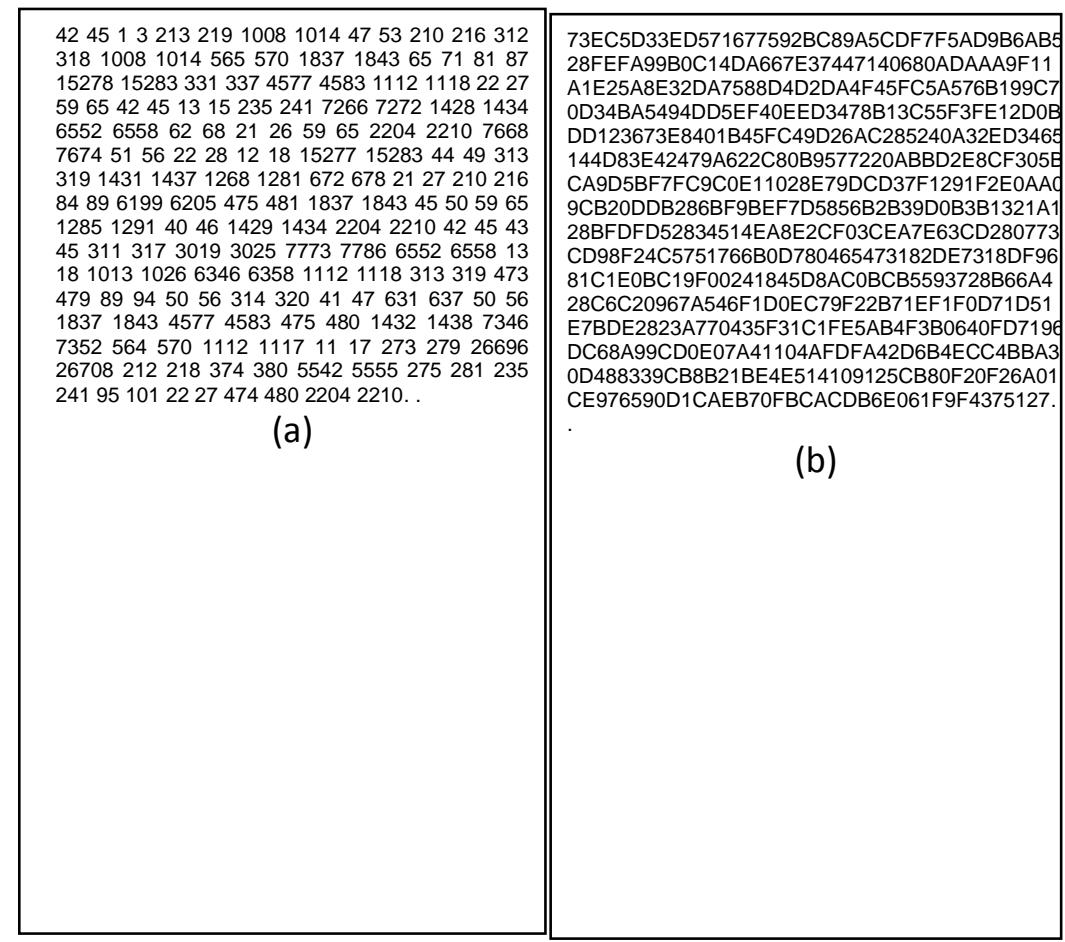

Gambar 6 (a) Indeks bit, (b) Indeks bit terenkripsi.

\section{2) Proses Ekstraksi}

Pada pengujian proses ekstraksi, penulis akan mengembalikan pesan dari hasil vektor yang telah terenkripsi dengan melakukan ekstraksi file tersebut. Sedangkan untuk waktu ekseskusi pada citra hitam puih dapat dilihat pada Tabel 1 dan waktu ekseskusi pada citra color dapat dilihat pada Tabel 2.

Langkah-langkah untuk melakukan proses ekstraksi adalah sebagai berikut:

a. Memilih vektor file, vektor_Baboon. txt

b. Memilih citra sebagai cover file, yaitu Baboon.bmp yang dapat dilihat seperti pada Gambar 5.

c. Menginputkan kunci. Kunci harus sama seperti saat melakukan embedding, yaitu "1234567".

d.Melakukan ekstraksi.

Setelah proses ekstrak pesan berhasil kembali seperti semula, dengan keluaran:

Transfer uang 50 juta via ATM.

Nomor rekening: 0123456

Password PIN: 9x8d7g

a. n. Budi Prasetiyo 
Kombinasi Steganografi Berbasis Bit Matching dan Kriptografi DES untuk

Tabel 1 Waktu ekseskusi pada citra hitam putih.

\begin{tabular}{llcccccc}
\hline \multirow{2}{*}{ No } & Citra & \multicolumn{3}{c}{ Embedding (detik) } & \multicolumn{3}{c}{ Ekstraksi(detik) } \\
& & Matching & Enkripsi & Total & Dekripsi & Rekonstruksi & Total \\
1. & Block.bmp & 1,327 & 24,265 & 25,82 & 25,044 & 0,397 & 25,86 \\
2. & Gradasi.bmp & 0,374 & 31,53 & 32,06 & 33,386 & 0,321 & 34,37 \\
& Rata-rata & 0,850 & 27,897 & 28,940 & 29,215 & 0,359 & 30,115 \\
\hline
\end{tabular}

Tabel 2 Waktu ekseskusi pada citra color.

\begin{tabular}{llcccccc}
\hline \multirow{2}{*}{ No } & Citra & \multicolumn{3}{c}{ Embed (detik) } & \multicolumn{3}{c}{ Ekstrak (detik) } \\
& & Matching & Enkripsi & Total & Dekripsi & Rekonstruksi & Total \\
1. & Lenna.bmp & 0,165 & 12,451 & 12,71 & 12,621 & 0,184 & 13 \\
2. & Pepper.bmp & 0,157 & 10,152 & 10,40 & 11,872 & 0,183 & 12,24 \\
3. & Jet.bmp & 0,138 & 11,828 & 12,06 & 12,131 & 0,154 & 12,46 \\
4. & Baboon.bmp & 0,162 & 10,121 & 10,37 & 10,143 & 0,138 & 10,45 \\
5. & Foto.bmp & 0,199 & 15,108 & 15,41 & 15,318 & 0,160 & 15,72 \\
& Rata-rata & 0,164 & 11,932 & 12,19 & 12,417 & 0,164 & 12,774 \\
\hline
\end{tabular}

Berdasar pengujian menunjukkan bahwa pada citra hitam putih diperoleh ratarata proses embedding 28,94 dtk dengan lama waktu pencocokan bit 0,850 dtk dan enkripsi 27,897 dtk. Rata-rata proses ekstraksi yaitu 30,115 dtk dengan lama dekripsi 29,215 dtk dan rekonstruksi pesan 0,359 dtk. Sedangkan pada citra warna, rata-rata proses embedding adalah 12,19 dtk dengan lama waktu untuk pencocokan bit 0,164 dan enkripsi 11,932. Pada proses ekstraksi membutuhkan waktu rata-rata $12,774 \mathrm{dtk}$ dengan lama waktu untuk dekripsi 12,417 dtk dan rekonstruksi pesan 0,1638 dtk.

\subsection{Hasil Pengujian dengan Berbagai Ukuran Resolusi}

Pengujian dengan berbagai ukuran citra mulai 512px, 256px, 128px dan 64px. Berdasar pengujian pada Tabel 3 menunjukkan bahwa semakin besar resolusi citra maka proses pencockan bit akan semakin lama. Rata-rata waktu pencocokan bit yang paling singkat yaitu "Baboon" (0,590 dtk), sedangkan pencocokan bit paling lama yaitu "Block" (2,022 dtk). Baboon memiliki variasi warna yang paling banyak, sedangkan "Block" hanya memiliki 2 variasi warna (hitam dan putih). 
Budi Prasetiyo, dkk.

Tabel 3 Hasil pengujian dengan berbagai ukuran citra.

\begin{tabular}{|c|c|c|c|c|c|c|c|}
\hline \multirow[t]{2}{*}{ Citra } & \multirow[t]{2}{*}{ Resolusi (px) } & \multicolumn{3}{|c|}{ Proses Embedding (dtk) } & \multicolumn{3}{|c|}{ Proses Ekstraksi (dtk) } \\
\hline & & Matching & Enkripsi & Total & Dekripsi & $\begin{array}{c}\text { Rekons- } \\
\text { truksi }\end{array}$ & Total \\
\hline \multirow[t]{5}{*}{ "Block" } & $512 \times 512$ & 5,576 & 6,576 & 7,576 & 8,576 & 9,576 & 10,576 \\
\hline & $256 \times 256$ & 1,706 & 30,165 & 32,133 & 29,587 & 0,409 & 30,703 \\
\hline & $128 \times 128$ & 0,548 & 31,673 & 32,375 & 27,225 & 0,338 & 28,096 \\
\hline & $64 \times 64$ & 0,256 & 24,033 & 24,417 & 23,873 & 0,320 & 24,594 \\
\hline & Rata-rata & 2,022 & 23,112 & 24,125 & 22,315 & 2,661 & 23,492 \\
\hline \multirow[t]{5}{*}{ "Gradation" } & $512 \times 512$ & 5,542 & 24,986 & 31,086 & 24,723 & 0,696 & 25,909 \\
\hline & $256 \times 256$ & 1,726 & 31,963 & 33,967 & 29,819 & 0,414 & 30,961 \\
\hline & $128 \times 128$ & 0,541 & 27,441 & 28,149 & 27,388 & 0,337 & 28,216 \\
\hline & $64 \times 64$ & 0,256 & 24,033 & 24,417 & 23,873 & 0,320 & 24,594 \\
\hline & Rata-rata & 2,016 & 27,106 & 29,405 & 26,451 & 0,442 & 27,420 \\
\hline \multirow[t]{5}{*}{ "Lena" } & $512 \times 512$ & 1,866 & 9,681 & 11,860 & 11,786 & 0,179 & 12,197 \\
\hline & $256 \times 256$ & 0,560 & 10,919 & 11,691 & 10,627 & 0,297 & 11,081 \\
\hline & $128 \times 128$ & 0,193 & 11,026 & 11,340 & 10,308 & 0,213 & 10,715 \\
\hline & $64 \times 64$ & 0,094 & 10,033 & 10,204 & 10,089 & 0,184 & 10,418 \\
\hline & Rata-rata & 0,678 & 10,415 & 11,274 & 10,703 & 0,218 & 11,103 \\
\hline \multirow[t]{6}{*}{ "Pepper" } & $512 \times 512$ & 1,861 & 9,637 & 11,988 & 9,460 & 0,568 & 10,170 \\
\hline & $256 \times 256$ & 0,646 & 10,097 & 10,922 & 10,545 & 0,275 & 10,997 \\
\hline & $128 \times 128$ & 0,239 & 10,214 & 10,587 & 10,265 & 0,237 & 10,998 \\
\hline & $64 \times 64$ & 0,095 & 9,427 & 9,639 & 9,547 & 0,136 & 9,824 \\
\hline & Rata-rata & 0,710 & 9,844 & 10,784 & 9,954 & 0,304 & 10,497 \\
\hline & $512 \times 512$ & 2,038 & 12,186 & 14,713 & 10,564 & 0,181 & 10,900 \\
\hline \multirow[t]{5}{*}{ "Jet" } & $256 \times 256$ & 0,567 & 11,341 & 12,095 & 11,099 & 0,267 & 11,574 \\
\hline & $128 \times 128$ & 0,221 & 10,714 & 11,039 & 10,704 & 0,183 & 11,503 \\
\hline & $64 \times 64$ & 0,089 & 10,734 & 10,902 & 10,575 & 0,179 & 10,946 \\
\hline & Rata-rata & 0,729 & 11,244 & 12,187 & 10,736 & 0,203 & 11,231 \\
\hline & $512 \times 512$ & 1,636 & 7,375 & 9,561 & 7,337 & 0,568 & 8,011 \\
\hline \multirow[t]{5}{*}{ "Baboon" } & $256 \times 256$ & 0,468 & 7,067 & 7,715 & 7,057 & 0,247 & 7,421 \\
\hline & $128 \times 128$ & 0,165 & 7,453 & 7,669 & 7,223 & 0,166 & 7,526 \\
\hline & $64 \times 64$ & 0,090 & 8,645 & 8,625 & 8,358 & 0,163 & 8,641 \\
\hline & Rata-rata & 0,590 & 7,635 & 8,393 & 7,494 & 0,286 & 7,900 \\
\hline & $512 \times 512$ & 2,444 & 14,795 & 17,751 & 14,742 & 0,563 & 15,541 \\
\hline \multirow[t]{3}{*}{ "Foto" } & $256 \times 256$ & 0,684 & 15,591 & 16,495 & 14,901 & 0,273 & 15,443 \\
\hline & $128 \times 128$ & 0,278 & 15,497 & 15,874 & 15,161 & 0,223 & 15,620 \\
\hline & $64 \times 64$ & 0,113 & 14,128 & 14,352 & 13,852 & 0,192 & 14,270 \\
\hline
\end{tabular}




\begin{tabular}{|c|c|c|c|c|c|c|c|}
\hline \multirow[t]{3}{*}{ Citra } & \multirow[t]{2}{*}{ Resolusi (px) } & \multicolumn{3}{|c|}{ Proses Embedding (dtk) } & \multicolumn{3}{|c|}{ Proses Ekstraksi (dtk) } \\
\hline & & Matching & Enkripsi & Total & Dekripsi & $\begin{array}{c}\text { Rekons- } \\
\text { truksi }\end{array}$ & Total \\
\hline & Rata-rata & 0,880 & 15,003 & 16,118 & 14,664 & 0,313 & 15,219 \\
\hline
\end{tabular}

Secara umum dapat ditarik kesimpulan bahwa rata-rata proses embedding pada citra hitam putih 2 kali lebih lama dibanding citra warna. Proses pencocokan bit pada citra dengan variasi warna banyak lebih singkat, daripada citra yang memiliki variasi warna sedikit. Hal ini disebabkan pada citra variasi warna banyak memungkinkan banyak peluang terjadinya kesamaan susunan bit antara bit pesan dan bit citra, sehingga memakan waktu lebih singkat.

\subsection{Pengujian dengan Pemberian Noise}

Citra yang digunakan pada proses embedding selanjutnya diberi noise' salt and pepper' yang dapat dilihat pada Gambar 7dan gaussian dapat dilihat pada Gambar 8. Citra diberi noise 'salt and pepper' dengan standar deviasi $d=$ 0,$001 ; 0,005 ; 0,01 ; 0,05$. Pemberian citra dengan noise 'gaussian' menggunakan mean noldan standar deviasi $d=0,001 ; 0,005 ; 0,01 ; 0,05$. Citra yang telah diberi noise kemudian diuji pada proses ekstraksi untuk mengembalikan pesan.

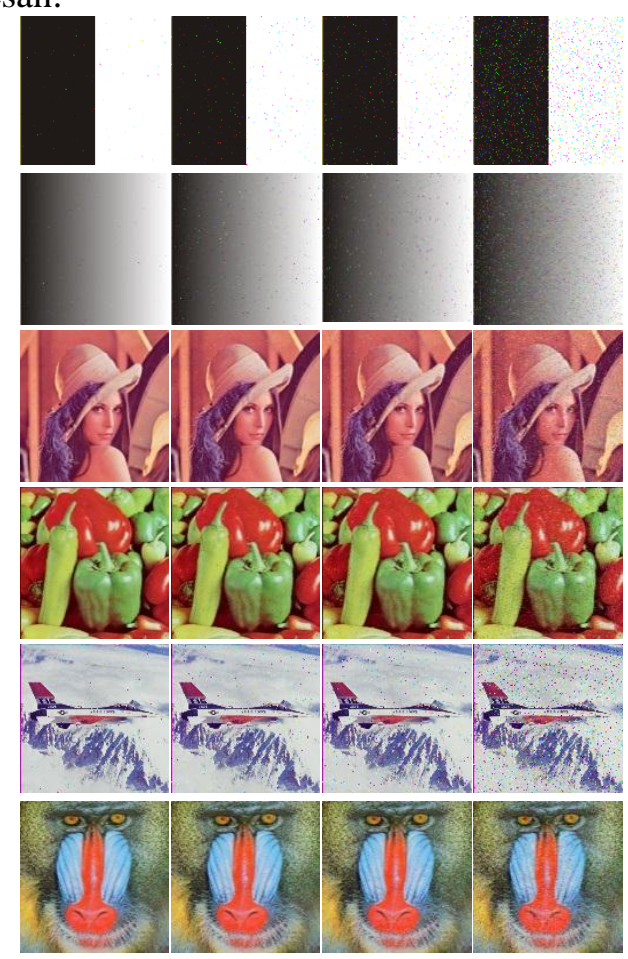


Budi Prasetiyo, dkk.

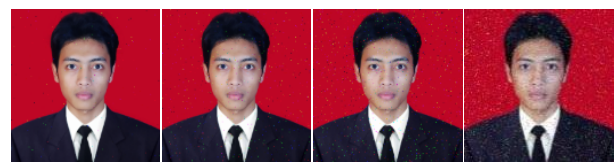

Gambar 7Citra dengan noise 'salt and pepper', (dari kiri ke kanan, $d=0,001 ; 0,005 ; 0,01 ; 0,05$ ).

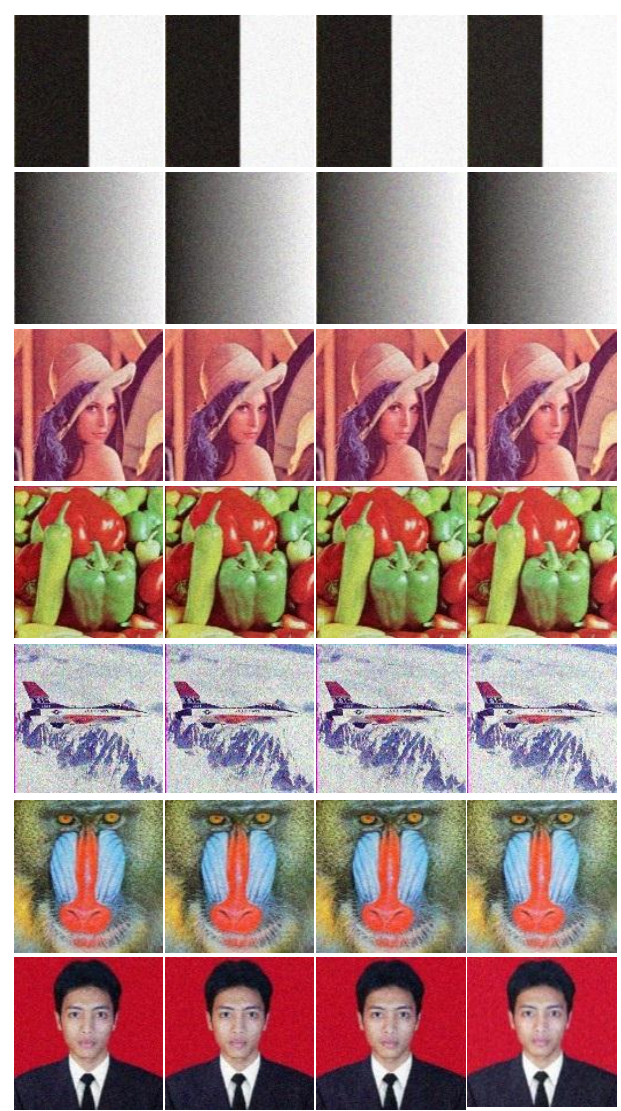

Gambar 8 Citra dengan noise 'Gaussian' mean nol, (dari kiri ke kanan, $d=0,001 ; 0,005 ; 0,01 ; 0,05$ ). 
Tabel 4 Hasil pengujian dengan Noise.

\begin{tabular}{|c|c|c|c|c|c|c|c|c|}
\hline \multirow{2}{*}{ Citra } & \multicolumn{4}{|c|}{ Salt \& pepper (d) } & \multicolumn{4}{|c|}{ Gaussian (mean $=0$ ) } \\
\hline & $\partial$ & MSE & PSNR & Pesan & $\partial$ & MSE & PSNR & Pesan \\
\hline \multirow{5}{*}{ "Lenna" } & 0,001 & 0,00030 & 34,987 & baik & $0,10 \%$ & 0,00307 & 52,3101 & Rusak \\
\hline & 0,005 & 0,00140 & 28,435 & baik & $0,50 \%$ & 0,00304 & 52,3080 & Rusak \\
\hline & 0,01 & 0,00310 & 25,014 & terbaca rusak & $1 \%$ & 0,00302 & 52,2815 & Rusak \\
\hline & 0,05 & 0,01400 & 18,282 & terbaca rusak & $5 \%$ & 0,00345 & 51,4609 & Rusak \\
\hline & 0,001 & 0,00010 & 67,295 & baik & $0,10 \%$ & 0,00328 & 52,4225 & Rusak \\
\hline \multirow{2}{*}{ "Pepper" } & 0,005 & 0,00483 & 50,094 & terbaca rusak & $0,50 \%$ & 0,00329 & 52,4045 & Rusak \\
\hline & 0,01 & 0,00094 & 57,320 & terbaca rusak & $1 \%$ & 0,00333 & 52,3485 & Rusak \\
\hline \multirow{6}{*}{ "Baboon" } & 0,05 & 0,00483 & 50,094 & terbaca rusak & $5 \%$ & 0,00404 & 51,3140 & Rusak \\
\hline & 0,001 & 0,00013 & 67,773 & baik & $0,10 \%$ & 0,00320 & 52,2707 & Rusak \\
\hline & 0,005 & 0,00049 & 60,369 & terbaca rusak & $0,50 \%$ & 0,00318 & 52,2517 & Rusak \\
\hline & 0,01 & 0,00091 & 57,660 & terbaca rusak & $1 \%$ & 0,00320 & 52,2316 & Rusak \\
\hline & 0,05 & 0,00494 & 50,410 & terbaca rusak & $5 \%$ & 0,00380 & 51,3988 & Rusak \\
\hline & 0,001 & 0,00014 & 61,398 & baik & $0,10 \%$ & 0,00322 & 48,2885 & Rusak \\
\hline \multirow{2}{*}{ "Jet" } & 0,005 & 0,00056 & 55,936 & baik & $0,50 \%$ & 0,00319 & 48,3709 & Rusak \\
\hline & 0,01 & 0,00123 & 52,807 & baik & $1 \%$ & 0,00321 & 48,2902 & Rusak \\
\hline \multirow{5}{*}{ "Foto" } & 0,05 & 0,00515 & 46,077 & terbaca rusak & $5 \%$ & 0,00379 & 47,6589 & Rusak \\
\hline & 0,001 & 0,00010 & 66,863 & baik & $0,10 \%$ & 0,00296 & 53,0124 & Rusak \\
\hline & 0,005 & 0,00067 & 59,135 & terbaca rusak & $0,50 \%$ & 0,00296 & 52,9414 & Rusak \\
\hline & 0,01 & 0,00116 & 56,401 & terbaca rusak & $1 \%$ & 0,00305 & 52,8322 & Rusak \\
\hline & 0,05 & 0,00601 & 49,286 & terbaca rusak & $5 \%$ & 0,00386 & 51,5197 & Rusak \\
\hline \multirow{3}{*}{ "Grad" } & 0,001 & 0,00009 & 67,871 & baik & $0,10 \%$ & 0,00310 & 52,4209 & Rusak \\
\hline & 0,005 & 0,00058 & 59,557 & baik & $0,50 \%$ & 0,00309 & 52,4483 & Rusak \\
\hline & 0,01 & 0,00108 & 56,889 & baik & $1 \%$ & 0,00311 & 52,4256 & Rusak \\
\hline \multirow{5}{*}{ "Block" } & 0,05 & 0,00538 & 50,026 & rusak & $5 \%$ & 0,00371 & 51,6761 & Rusak \\
\hline & 0,001 & 0,00012 & 65,675 & baik & $0,10 \%$ & 0,00220 & 54,0692 & terbaca rusak \\
\hline & 0,005 & 0,00069 & 58,685 & baik & $0,50 \%$ & 0,00221 & 54,0967 & terbaca rusak \\
\hline & 0,01 & 0,00163 & 55,358 & baik & $1 \%$ & 0,00216 & 54,1347 & Rusak \\
\hline & 0,05 & 0,00745 & 48,624 & baik & $5 \%$ & 0,00234 & 53,6779 & terbaca rusak \\
\hline
\end{tabular}

Hasil rekonstruksi pesan pada citra hitam putih dengan penambahan noise salt \& pepper tetap baik. Pesan dapat dibaca, kecuali 1 yang mengalami kerusakan. Pada citra warna sebagian besar mengalami kerusakan, kecuali citra "Jet" dan "Lenna" yang mengalami sedikit kerusakan dengan nilai MSE paling tinggi 0,014 . Kerusakan pada citra warna terjadi mulai MSE 0,0067 pada citra "Foto" yang notabene memiliki variasi warna cukup sederhana. Penambahan noiseGausian membuat sebagian besar isi pesan rusak. Kerusakan mulai terjadi pada nilai MSE 0,00234. Hal ini disebabkan penambahan noise mempengaruhi nilai bit citra, sedangkan pencocokan bit mengambil pada indeks posisi bit yang tepat. Sehingga hasil rekonstruksi pesan akan menghasilkan pesan yang berubah pula. 


\section{SIMPULAN}

Proses steganografi pada penelitian ini meliputi pencocokan bit dan rekonstruksi, sedangkan proses kriptografimeliputi enkripsi dan dekripsi. Kombinasi steganografi dan kriptografi pada penelitian ini dapat digunakan untuk pengamanan data. Masukan data pesan, citra dan kunci. Hasilnya adalah chipterteks. Untuk mengetahui isi pesan dibutuhkan kunci dan citra yang sama.

Citra grayscale maupun citra warna dapat digunakan sebagai media cover. Kecuali citra dengan warna $100 \%$ hitam atau $100 \%$ putih, karena citra tersebut terdiri dari susunan bit yang homogen. Semua nilai bit pada citra $100 \%$ bernilai 0 (nol) dan citra 100\% hitam bernilai 1 (satu), padahal susunan bit pesan bervariasi antara 0 dan 1 , sehingga pencocokan bit tidak akan menemukan hasil.

Penambahan noise pada citra mengakibatkan sebagian isi pesan berubah, dengan tingkat perubahan yang bervariasi. Pada citra hitam putih tidak terjadi perubahan yang berarti, namun pada citra warna terjadi banyak perubahan isi pesan. Kerusakan terjadi pada penambahan salt and peper mulai nilai MSE 0,0067 dan pada gaussian mulai terjadi kerusakan pada MSE 0,00234.

Proses pencocokan bit dengan variasi wana yang banyak lebih singkat dibanding citra dengan variasi warna yang lebih sedikit. Kelebihan metode ini diantaranya kualitas citra tidak dirubah. Dari segi pengamanan, seandainya vektor indeks bit tidak di enkripsi sebenarnya sudah cukup untuk mengamankan data. Karena untuk mengembalikan indeks menjadi pesan dibutuhkan citra yang tepat, jika tidak maka hasilnya tidak akan terbaca. Peneliti lain bisa melakukan enkripsi pada citra terlebih dahulu sebelum dilakukan pencocokan bit. Operasi pada citra juga dapat dilakukan agar citra $100 \%$ hitam maupun $100 \%$ putih dapat dijadikan sebagai cover. Disamping itu peneliti lain bisa memodifikasi output chiperteks menjadi stego image.

\section{REFERENSI}

[1] Kautzar, M. G., Studi Kriptografi Mengenai Triple DES dan AES, ITB, Bandung, 2007.

[2] Provos, N. \& Honeyman, P., Hide and Seek: An Introduction to Steganography, IEEE Security \& Privacy Vol. 1(3), 32-44, 2003.

[3] Schneier, B., Applied Cryptography 2nd Edition, Wiley \& Sons. Inc., New York, 1996.

[4] Krenn, R., Steganography and Steganalysis, Whitepaper, 2004. 
[5] Raphael., Sundaram, A. J. \& Sundaram, V., Cryptography and Steganography - A Survey, International Journal Comp. Tech. Applied Vol. 2 (3), 626-630, 2011.

[6] Chan, C. K. \& L. M. Cheng., Hiding Data in Images by Simple LSB Substitution, Pattern Recognition Vol. 37(3), 469-474, 2004.

[7] Challita, K. \& Farhat, H., Combining Steganography and Cryptography: New Directions, International Journal on New Computer Architectures and Their Applications (IJNCAA) 1(1), 199-208, 2011.

[8] Pressman, R. S., Software Engineering: A Practitioner's Approach, $6^{\text {th }}$ Edition, The McGraw-Hill Companies, Inc, Singapore, 2001.

[9] Cormen, T. H., Leiserson C. E., Rivest R. L. \& Stein D., Introduction to Algorithms, Third Edition, The MIT Press, England, 2009.

[10] Kekre, H. B., Archana A. \& Pallavi N. H., Comparison between the basic LSB Replacement Technique and Increased Capacity of Information Hiding in LSB's Method for Images, International Journal of Computer Applications (0975 - 8887) Vol . 45 (1), 33-38, 2012.

[11] Menezes A. J., Oorschot, P. C. \& Vanstone, S. A., Handbook of Applied Cryptography, CRC Press, Boca Raton, New York, 1996.

[12] Munir, R., Pengantar Kriptografi, ITB, Bandung, 2006.

[13] Narayana, S. \& Prasad, G., Two New Approaches for Secured Image Steganography Using Cryptographic Techniques and Type Conversions, Signal \& Image Processing: An International Journal (SIPIJ) Vol. 1(2), 60-73, 2010.

[14] Seth, D., Ramanathan, L. \& Pandey, A., Security Enhancement: Combining Cryptography and Steganography, International Journal of Computer Applications (0975 - 8887) Vol. 9 (11), 3-6, 2010.

[15] Sharp, T., An implementation of Key-based Digital Signal Steganography,Proc. Information Hiding Workshop Vol. 2137, Springer LNCS, 13-26, 2001. 
94 | Scientific Journal of Informatics, Vol. 1, No. 1, Mei 2014, ISSN 2407-7658 